\title{
Ocular non-Hodgkin's lymphoma: a clinical study of nine cases
}

Hugo E Verbraeken, Michel Hanssens, Hildegaard Priem, Bart A Lafaut, Jean-Jacques De Laey

\begin{abstract}
Background-Primary oculocerebral large cell malignant non-Hodgkin's lymphoma, formerly called ocular reticulum cell sarcoma, runs a uniformly fatal course. Once the central nervous system (CNS) is involved, survival without treatment is very limited. Although treatment does not substantially improve the long term survival, it provides short term improvement in these patients.

Methods-The charts of all patients with ocular involvement of non-Hodgkin's lymphoma followed during the period 1984-93 were reviewed. The diagnosis of non-Hodgkin's lymphoma was made by different diagnostic approaches: CNS biopsy, anterior chamber tap, vitrectomy, haematology, and necropsy.

Results-Eight patients had oculocerebral large cell and one had small cell nonHodgkin's lymphoma. Five patients with pure ocular localisation had initially received steroid treatment for intermediate uveitis. First diagnosis was made on CNS biopsy in three, anterior chamber tap in one, vitreous aspirate in three, haematology in one, and necropsy in one case. Conclusion-Ocular non-Hodgkin's lymphoma is a difficult diagnosis. Vitrectomy allows cytological diagnosis in most but not all cases. When no treatment is given, patients survive for only a few weeks once the CNS is involved. Although the disease is eventually fatal, treatment by means of radiotherapy, steroid administration, and vitrectomy can allow these patients to lead a normal professional and social life during the years between recurrences.
\end{abstract}

Department of

Ophthalmology,

University Hospital of

Ghent, Belgium

$\mathrm{H}$ E Verbraeken

M Hanssens

$\mathrm{H}$ Priem

B A Lafaut

J-J De Laey

Correspondence to:

Hugo Verbraeken,

Department of

Ophthalmology, University

Hospital of Ghent, De

Pintelaan, 185, 9000 Ghent,

Belgium.

Accepted for publication 26 August 1996

An increasing number of cases of ocular non-Hodgkin's lymphoma is being reported. While ocular involvement in Hodgkin's lymphoma is rare, ${ }^{1}$ it is a frequent affection in non-Hodgkin's lymphomas. Two forms can be recognised clinically ${ }^{2}$ : primary oculo-central nervous system (CNS) non-Hodgkin's lymphoma and systemic non-Hodgkin's lymphoma with secondary metastatic ocular involvement.

Primary ocular non-Hodgkin's lymphoma was previously called ocular reticulum cell sarcoma, but is now classified as large cell non-
Hodgkin's lymphoma. Ocular location is mainly vitreal and retinal.

Primary ocular non-Hodgkin's lymphoma is frequently followed by CNS non-Hodgkin's lymphoma later on in the course of the disease, ${ }^{2-4}$ while primary CNS lymphoma is associated only in $12-15 \%$ of the cases with ocular involvement. Ocular non-Hodgkin's lymphoma is estimated to occur as oculo-CNS disease in $61 \%$, ocular in $17 \%$, oculo-visceral in $17 \%$, and oculo-visceral-CNS in $5 \%$ of the cases. $^{35}$

Primary ocular non-Hodgkin's lymphoma typically masquerades as uveitis. ${ }^{23}$ Most of these patients received steroid treatment for an intermediate or posterior uveitis before the diagnosis of ocular non-Hodgkin's lymphoma was made. The lymphoma cells penetrate the vitreous, the retina, the subretinal pigment epithelium, and the optic nerve. Multiple small lesions of the retinal pigment epithelium, seen as round or oval, white creamy masses, are considered as pathognomonic. ${ }^{267}$ Early diagnosis is only possible by careful clinical examination and a high degree of suspicion.

Ocular involvement in systemic nonHodgkin's lymphoma is rare. ${ }^{23}$ Ocular involvement is due to a secondary metastatic spread of the lymphoma in the choroid and sometimes in the anterior chamber. ${ }^{810}$

Life expectancy in cases of primary oculoCNS large cell non-Hodgkin's lymphoma is limited. However, remissions can be obtained if the disease is diagnosed early and is treated effectively. Quality of life can be improved both ophthalmologically and neurologically. ${ }^{211}$ Small cell non-Hodgkin's lymphoma is considered as a low grade malignancy and thus has a more favourable prognosis. In this study nine patients with ocular non-Hodgkin's lymphoma are presented-eight with a large cell nonHodgkin's lymphoma and one with a visceral small cell non-Hodgkin's lymphoma.

\section{Material and methods}

All cases of non-Hodgkin's lymphoma with ocular involvement, followed in our department during the period 1984-93, are included in this study. Sex, age at diagnosis, the primary localisation of the tumour, the method of diagnosis and treatment, as well as the recurrences and ocular complications were recorded.

The diagnosis was made by different approaches: CNS biopsy, anterior chamber tap, (Table 1). vitreous aspirate, haematology, and at necropsy 
Table 1 Diagnostic method

\begin{tabular}{ll}
\hline CNS biopsy & 3 \\
Anterior chamber tap & 1 \\
Vitreous aspiration & 3 \\
Blood/serum analysis & 1 \\
$\mathrm{Rx}, \mathrm{CT}, \mathrm{MR}+$ history + histology post mortem & 1 \\
\hline
\end{tabular}

In some patients with known CNS or visceral involvement, vitrectomy or chorioretinal biopsy was performed to confirm the ocular disease and to guide further treatment. All patients underwent a complete haematological staging once a non-Hodgkin's lymphoma was suspected. The staging consisted of haematological and chemical analysis, bone marrow biopsy, thorax radiography, computed tomography scan of brain and abdomen, and spinal fluid examination.

Vitrectomy was performed by a classic two or three port pars plana technique with incisions at $4 \mathrm{~mm}$ from the limbus. Using a low cut rate of the vitreotome, the first $3 \mathrm{ml}$ of the vitreous aspirate were collected separately and processed immediately for evaluation by an experienced cytologist.

\section{Results}

The files of nine patients, six men and three women, were studied. They all were immunocompetent. The age at the time of diagnosis varied from 36 to 75 years with an average of 60 years (Table 2 ).

Ocular manifestations were the first symptoms of the disease in four patients. Ocular and CNS localisations were diagnosed simultaneously in a fifth patient. Two patients already had CNS involvement at the start of their ocular complaints. One patient had CNS and visceral lymphoma before the onset of his ocular complaints. A last patient was already being followed for a visceral small cell non-Hodgkin's lymphoma at the onset of ocular symptomatology.

All patients with large cell non-Hodgkin's lymphoma eventually had ocular and CNS involvement. The patient with the visceral non-Hodgkin's lymphoma subsequently developed meningeal involvement.

The diagnosis was made on CNS biopsy for three patients (cases $1,3,8$ ), anterior chamber tap for one (case 2), vitrectomy aspirate for three (cases 4, 5, 6), and haematochemical analysis for one (case 9). The diagnosis was made only at necropsy for patient 7 .

Vitrectomy was performed in nine eyes of six patients. Cytological examination of the vitreous aspirate was positive for lymphoma in six eyes and questionable in three eyes. Of the three patients undergoing a vitrectomy in both eyes, both vitrectomies were positive for one patient. The two other patients each had one positive and one negative cytological examination.

Chorioretinal biopsy confirmed the choroidal localisation of the small cell lymphoma in one patient with visceral small cell nonHodgkin's lymphoma and secondary oculomeningeal involvement (case 9).

The four patients (cases 2, 3, 7, 8) with initial CNS localisation (two pure CNS, one
CNS ocular, one CNS visceral) were treated with total brain irradiation (48 Gy, 45 Gy, 45 Gy, 55 Gy, respectively). One patient (case 2) was free from CNS disease for 5 years until a fatal recurrence. In between he had two ocular involvements (each eye once). The first eye was affected 1 year after the diagnosis and treated by vitrectomy and orbital radiotherapy (35 Gy). This treatment was complicated by a corneal ulcer. The second eye also underwent vitrectomy. Both eyes developed cataract. One eye was surgically treated with an extracapsular cataract extraction and posterior chamber lens implant. One patient (case 3) suffered from a fatal CNS recurrence 3 years after the initial lesion. One patient (case 7) had ocular involvement 4 months after the diagnosis. Two months later a fatal CNS recurrence appeared.

The fourth patient (case 8) who underwent neurosurgery with a negative histological examination 4 years earlier had a new CNS biopsy with a positive result and he was treated with radiotherapy ( 45 Gy total brain + 10 Gy directed at the base of the skull). He developed cataract in both eyes. One year later he presented ocular signs of non-Hodgkin's lymphoma which was treated with vitrectomy and orbital radiotherapy (45 Gy). An extracapsular lens extraction with lens implantation was performed at the time of vitrectomy. The patient has survived the initial surgery for 6 years but is in poor general condition.

Four patients (cases 1, 4, 5, 6) initially presented only pure ocular localisation. One patient (case 1), who was treated with steroids for uveitis, subsequently developed neurological symptoms, compatible with tuberculous meningitis. A few weeks later neuroradiological images revealed a pontocerebellar tumor. She underwent a craniotomy with partial resection of a cerebellar tumour, of which histopathological examination showed it to be a primary lymphoma WHO class IV. The patient remained subcomatous postoperatively, developed lung infiltrates, and died 2 months later. The eyes were studied at necropsy. Tumour cells, identified as immunoblastoma, were seen in clusters between the retinal pigment epithelium and Bruch's membrane. Tumour cells were also found surrounding the retinal vessels and breaking through the internal limiting membrane into the vitreous. Occasional lymphoma cells were also noticed in the choroid.

The second patient (case 4) was treated with vitrectomy and orbital radiotherapy (50 Gy). Nine months later a fatal CNS involvement resulted in a subcoma and the patient eventually died 14 months after the diagnosis.

The third patient (case 5) was treated with steroids as the vitrectomy aspirate was cytologically negative. Ten months later the other eye was involved. At that time a mediastinal tumour was found. The vitrectomy aspiration, performed in the second eye, showed the presence of non-Hodgkin's lymphoma. The treatment consisted of bilateral orbital radiotherapy (45 Gy) and systemic and intrathecal chemotherapy. The patient developed cataract in both eyes. She suffered from an ocular recurrence 2 
years after the initial attack which was treated with vitrectomy and lensectomy together with topical steroids. A year later a first CNS localisation was noticed. Treatment consisted of total brain irradiation (44 Gy) and a new cure of systemic and intrathecal chemotherapy. A year later the second eye was involved again and a vitrectomy and lensectomy were performed. She had a CNS recurrence which was treated anew with systemic chemotherapy but she died 5 years after the initial ocular symptoms.
The fourth patient (case 6) was treated with vitrectomy, systemic steroids, and orbital radiotherapy (55 Gy). The second eye was involved 6 months later and was treated with systemic steroids and chemotherapy. A year and a half after the diagnosis she developed a fatal brain localisation despite total brain irradiation (45 Gy).

At the end of 1993 seven of the eight patients with large cell non-Hodgkin's lymphoma had died. All patients died between 6 months and 6 years after the diagnosis with an average

Table 2 History of the patients

\begin{tabular}{|c|c|c|c|c|c|c|c|c|}
\hline \multirow[b]{2}{*}{ Case } & \multirow[b]{2}{*}{ Sex/age } & \multirow[b]{2}{*}{ Site and recurrences } & \multirow[b]{2}{*}{ Treatment } & \multicolumn{2}{|c|}{ Survival since } & \multirow[b]{2}{*}{ Diagnosis } & \multirow[b]{2}{*}{ Pathology } & \multirow[b]{2}{*}{ Complications - evolution } \\
\hline & & & & 1st sign & $\begin{array}{l}1 s t \\
\text { ocular }\end{array}$ & & & \\
\hline \multirow[t]{4}{*}{1} & \multirow[t]{4}{*}{$\mathrm{F} / 60$} & $\mathrm{O}, \mathrm{IU}, \mathrm{CH}$ & Cort, top, SC & \multirow[t]{4}{*}{$6 \mathrm{~m}$} & \multirow[t]{4}{*}{$6 \mathrm{~m} \dagger$} & & & Uveitis since 4 months \\
\hline & & $\mathrm{C}, 4 \mathrm{~m}$ & Surgery & & & $\mathrm{APC}$ & OML & $\begin{array}{l}\text { First treated as tuberculous meningitis } \\
\text { Coma after craniotomy }\end{array}$ \\
\hline & & & & & & & & Pontocerebellar tumour \\
\hline & & $\begin{array}{l}\mathrm{O}, 2 \text { nd eye } 5 \mathrm{~m}, \mathrm{IU} \\
\mathrm{CH}\end{array}$ & Cort, top & & & AP eye post $†$ & OML & $t$ \\
\hline \multirow[t]{3}{*}{2} & \multirow[t]{3}{*}{$\mathrm{M} / 59$} & C, putamen & $\begin{array}{l}\text { Surgery } \\
\mathrm{Rx} 48 \mathrm{~Gy} \mathrm{O}+\mathrm{C}\end{array}$ & \multirow[t]{3}{*}{$6 \mathrm{y}$} & \multirow[t]{3}{*}{5 y† } & $\mathrm{APC}$ & OML & \\
\hline & & $\mathrm{O}, 1 \mathrm{y}, \mathrm{IU}, \mathrm{CH}$ & $\begin{array}{l}\text { Vitr } \\
\text { Rx } 35 \text { Gy O }\end{array}$ & & & Vitr & OML & Corneal ulcer after $\mathrm{Rx}$ \\
\hline & & $\mathrm{O}, 3$ y, IU, CH & $\begin{array}{l}\text { Vitr } \\
\text { Cort, top }\end{array}$ & & & Vitr & - & Cataract $\rightarrow$ ECCE + IOL \\
\hline \multirow[t]{3}{*}{3} & \multirow[t]{3}{*}{$\mathrm{F} / 75$} & $\begin{array}{l}\mathrm{O}+\mathrm{C}, \mathrm{IU}, \mathrm{CH}, \\
\text { occipit, tumour }\end{array}$ & $\mathrm{Rx} 45 \mathrm{~Gy} \mathrm{O}+\mathrm{C}$ & \multirow[t]{3}{*}{$3 y$} & \multirow[t]{3}{*}{3 y† } & \multirow[t]{3}{*}{ ACT } & \multirow[t]{3}{*}{ OML } & Uveitis since 1 year \\
\hline & & & Cort, SC + sys & & & & & \\
\hline & & $\mathrm{C}, 3 \mathrm{y}$ & & & & & & $\begin{array}{l}\text { Vertigo, gen condition } \downarrow \\
\text { Paresis lower limb }\end{array}$ \\
\hline \multirow[t]{2}{*}{4} & $\mathrm{M} / 75$ & $\mathrm{O}, \mathrm{IU}, \mathrm{CH}$ & $\begin{array}{l}\text { Vitr } \\
\text { Rx } 50 \text { Gy O }\end{array}$ & $14 \mathrm{~m}$ & $14 \mathrm{~m} \dagger$ & Vitr & OML & Uveitis both eyes since 6 months \\
\hline & & $\mathrm{C}, 9 \mathrm{~m}$ & & & & & & Subcoma cerebral extension tumour $\dagger$ \\
\hline 5 & $\mathrm{~F} / 35$ & $\mathrm{O}, \mathrm{CH}, \mathrm{IU}$ & Cort, top, SC, sys & $5 \mathrm{y}$ & $5 \mathrm{y} \dagger$ & Vitr & - & Uveitis since 15 months both eyes \\
\hline & & $\begin{array}{l}\mathrm{O}+\mathrm{M}, 2 \mathrm{nd} \text { eye IU, } \\
\mathrm{CH}, 10 \mathrm{~m}\end{array}$ & Vitr & & & Vitr & OML & \\
\hline & & & $\begin{array}{l}\text { Rx } 45 \text { Gy O both eyes } \\
\text { Chemo }(1)+(4)\end{array}$ & & & & & \\
\hline & & $\mathrm{O}, \mathrm{CH}, \mathrm{IU} 2 \mathrm{y}$ & Vitr + lensect & & & & & Cataract both eyes $>$ vision $20 / 20$ \\
\hline & & & Cort, top & & & & & \\
\hline & & $\begin{array}{l}\text { C, cerebellum basal } \\
\text { ganglia, } 3 \mathrm{y}\end{array}$ & $\mathrm{Rx} 44 \mathrm{~Gy} \mathrm{O}+\mathrm{C}$ & & & & & \\
\hline & & & Chemo (1) + (4) & & & & & \\
\hline & & $\mathrm{O}, \mathrm{CH}, \mathrm{IU} 4 \mathrm{y}$ & Cort, top & & & & & \\
\hline & & & Vitr + lensect & & & & & \\
\hline & & C, $5 \mathrm{y}$ & Cort, sys & & & & & No more reaction $\dagger$ \\
\hline 6 & $M / 62$ & $\mathrm{O}, \mathrm{IU}+$ ret det & Vitr & $2 \mathrm{y}$ & $2 \mathrm{y} \dagger$ & Vitr & OML & Uveitis since 7 months \\
\hline & & & $\begin{array}{l}\text { Cort, top, sys } \\
\text { Rx } 55 \text { Gy O }\end{array}$ & & & & & Corneal ulcer \\
\hline & & $\mathrm{O}, 2 \mathrm{nd}$ eye $6 \mathrm{~m}, \mathrm{IU}$ & $\begin{array}{l}\mathrm{K} x \mathrm{~s} \text { Gy } \\
\text { Chemo (2) }\end{array}$ & & & Vitr & OML & \\
\hline & & & Cort, top, sys & & & vilu & ONIL & \\
\hline & & $\mathrm{C}, 1 \mathrm{y}$ & $\mathrm{Rx} 45 \mathrm{~Gy} \mathrm{O}+\mathrm{C}$ & & & & & Cerebral extension $\dagger$ \\
\hline 7 & $\mathrm{M} / 54$ & $\mathrm{C}+\mathrm{P}$, pons cerebellum & Rx45 Gy O + C & $6 \mathrm{~m}$ & $2 \mathrm{~m} \dagger$ & & & Vertigo since 4 months \\
\hline & & & Cort, gen & & & & & $\begin{array}{l}\text { CT scan tumoral masses in pons, } \\
\text { cerebellum, lungs, corneal ulcer }\end{array}$ \\
\hline & & $\mathrm{V}$, lungs & & & & & & \\
\hline & & $\mathrm{O}, \mathrm{IU}+\mathrm{RD} 4 \mathrm{~m}$ & Vitr + ret & & & $\begin{array}{l}\text { Vitr } \\
\text { AP eye post } †\end{array}$ & $\overline{\mathrm{OML}}$ & VA $1 / 20 \dagger$ \\
\hline 8 & $\mathrm{M} / 53$ & C, frontal lobe & Surgery & $6 y$ & $5 \mathrm{y}$ & APC & - & CT scan several suggestive masses \\
\hline & & $\mathrm{O}, 9 \mathrm{~m}, \mathrm{IU}$ & Cort, top, SC & & & & & Treated as uveitis \\
\hline & & $\mathrm{O}, 20 \mathrm{~m}$ & Cort, top, SC, sys & & & & & Both eyes, glaucoma \\
\hline & & C, 4 y, temporal lobe & Surgery & & & APC & OML & Cataract both eyes \\
\hline & & & $\begin{array}{l}\text { Rx } 45 \text { Gy + } 10 \text { Gy skull } \\
\text { base O + C }\end{array}$ & & & & & \\
\hline & & $\mathrm{O}, 5 \mathrm{y}, \mathrm{IU}+\mathrm{CH}$ & $\begin{array}{l}\text { Vitr, Rx } 45 \text { Gy O both } \\
\text { eyes }\end{array}$ & & & Vitr & $\mathrm{OML}$ & Vitr + ECCE + IOL \\
\hline & & & & & & & & $\begin{array}{l}\text { Other eye IU + cataract } \\
\text { Poor general health }\end{array}$ \\
\hline 9 & $\mathrm{M} / 60$ & $\mathrm{~V}$, spleen & & $1 \mathrm{y}$ & $1 \mathrm{y}$ & Serum blood & SCL & \\
\hline & & lymphadenopathy & & & & & & \\
\hline & & $\begin{array}{l}\mathrm{O}+\mathrm{C}, 1 \mathrm{y} \text {, choroidal } \\
\text { meningeal }\end{array}$ & Chemo (3) + (4) & & & Chorioret & SCL & \\
\hline & & & $\begin{array}{l}\mathrm{Rx} 30 \mathrm{~Gy} \mathrm{O}+\mathrm{C} \\
\text { Cort, sys }\end{array}$ & & & & & \\
\hline
\end{tabular}

$\mathrm{O}=$ ocular $; \mathrm{C}=$ cerebral; $\mathrm{M}=$ mediastinum; $\mathrm{V}=$ visceral $\mathrm{IU}=$ intermediate uveitis $\mathrm{CH}=$ chorioretinitis; $\mathrm{RD}=$ retinal detachment Chor $=$ choroidal $;$ Age $=$ at time of diagnosis; Chorioret $=$ chorioretinal biopsy; Site = initital localisation and recurrences with time lapse from diagnosis; $y=$ year $(\mathrm{s}) ; \mathrm{m}=\mathrm{month}(\mathrm{s})$; $\mathrm{AP}=\mathrm{anatomopa-}$ thology; APC = pathology cerebral biopsy; ACT = anterior chamber tap; Vitr = vitrectomy; $\uparrow=$ deceased; Cort = cortisone; top = topical; $\mathrm{SC}=$ subconjunctival; sys $=$ systemic $; \mathrm{Rx}=$ radiotherapy; chemo = chemotherapy ECCE $=$ extracapsular cataract extraction $; \mathrm{IOL}=$ intraocular lens implant; OML = ocular malignant nonHodgkin's lymphoma; SCL = small cell non-Hodgkin's lymphoma.

Chemotherapy: systemic: (1) Vepesid, cyclophosphamide, Adriamycin; (2) Adriablastine, cyclophosphamide, Vepesid, Oncovin, Cytosar; (3) Leukeran: intrathecal: (4) Methotrexate. 
survival of 31 months. One patient (case 8) has survived the clinical diagnosis for 6 years, but is in poor general health.

Case 9 had a visceral small cell lymphoma but refused chemotherapy for 3 years. He subsequently developed ocular and meningeal involvement with progressive loss of vision. After a positive chorioretinal biopsy, he received total brain irradiation (30 Gy) and systemic as well as intrathecal chemotherapy. The papilloedema regressed and visual acuity dramatically improved. He has been stable for about 1 year. This case has been reported extensively elsewhere. ${ }^{7}$

Eight of our patients had so called 'vitritis'. Five of these had widespread small chorioretinal lesions. Three had no demonstrable participation of the chorioretina. One patient (case 9) had a clear vitreous with pure choroidal localisation of the lesions.

\section{Discussion}

SEX

In our small series we found a two to one male/ female ratio. In some publications a reversed sex ratio can be found. ${ }^{21}$ We have no clear explanation for this, except that most published series are small (9-24 patients). Other authors also reported a male preponderance. ${ }^{4}$

AGE AT TIME OF DIAGNOSIS

The mean age at diagnosis was 60 years. Ocular malignant non-Hodgkin's lymphoma mainly involves the elderly. ${ }^{2-41}$ This does not imply that the disease always spares younger people. Our youngest patient was a woman of 36 years who died 5 years after the diagnosis (case 5). Recently, a 15-year-old patient has been reported. ${ }^{2}$

FIRST LOCALISATION

Patients with visceral non-Hodgkin's lymphoma usually already have signs and symptoms of the systemic disease before ocular involvement. ${ }^{34}$ The eye is affected secondarily through a metastatic spread of the cells in the choroidal circulation. Most of these patients are known to have lymphoma at the time of ocular involvement.

In the primary ocular CNS non-Hodgkin's lymphomas, called ocular reticulum cell sarcoma in the older literature, ocular symptoms often precede CNS involvement. ${ }^{2-4}$ Pure intraocular non-Hodgkin's lymphoma occurs in $17-21 \%$ of the cases. Other patients sooner or later develop CNS and/or visceral involvement. This results in $61 \%$ of ocular CNS, $17 \%$ ocular visceral, and 5\% ocular visceral-CNS involvement. $^{2-4}$

The cases of malignant non-Hodgkin's lymphoma in our series started with pure ocular symptoms in four patients, while two patients had primary CNS involvement, one patient oculo-CNS disease, and another one CNS visceral involvement. This is comparable with previous reports ${ }^{4112}$ : half of the patients start with primary ocular involvement, about a third with CNS disease, and a smaller number with some combinations. One author reports that ocular symptoms precede CNS involvement in $80 \%$ of the cases. ${ }^{3}$

CNS INVOLVEMENT AFTER PRIMARY OCULAR

LOCALISATION

All our patients in the malignant nonHodgkin's lymphoma group developed CNS involvement during the course of their disease. The incidence of other series varies between $60 \%$ to $90 \%$ in the literature. ${ }^{2-4}$ The eye is to be considered as an extension of the brain. The CNS and the eye, in fact, form one organ, so that we are dealing with the same disease in the same organ. ${ }^{2}$ Postmortem histopathological examination often reveals multiple small foci of the disease, in the CNS as well as in the eye. ${ }^{2}$

OCULAR LYMPHOMA MASQUERADING AS

INTERMEDIATE UVEITIS

The five cases with primary ocular involvement (four isolated and one with simultaneous CNS involvement) had all been treated as intermediate uveitis with topical, peribulbar, and/or systemic steroids for periods ranging from 4 to 15 months. This has been commonly reported in other publications. ${ }^{2-411} 13$

This underlines the importance of thinking of a possible lymphoma in cases of chronic uveitis no longer responding to steroid treatment, although the initial regression of symptoms with steroid treatment may be misleading.

The 'vitritis' symptoms of non-Hodgkin's lymphoma should be differentiated from some non-neoplastic diseases such as old retinal detachment, long standing presence of intraocular foreign body, reactive lymphomatous hyperplasia, or low grade endophthalmitis. It should also be differentiated from other neoplastic diseases such as leukaemic infiltration or malignant melanoma of the choroid. ${ }^{3}$

ROLE OF VITRECTOMY

A diagnosis of ocular lymphoma can only be made when intentionally searched for. This means that the ophthalmologist should consider this diagnosis when facing a case of chronic posterior uveitis no longer responding to steroid treatment. Especially in cases where the patient is an older adult and/or where ophthalmoscopy reveals multiple small round punched out chorioretinal lesions, suspicion should exist and diagnostic vitrectomy should be considered. ${ }^{6}$

Secondly, one should also consider the possibility of a lymphoma when performing a vitrectomy for a cloudy vitreous. It is imperative that the aspirate should be examined immediately by a trained cytologist. These facts are stressed in several publications. ${ }^{41213}$ Sometimes, however, the diagnosis is only made at necropsy.

The examination of the vitreous aspirate can provide evidence for the diagnosis in a number of cases, but can also be negative. ${ }^{24121415}$ In our series vitrectomy provided a conclusive answer in six of nine eyes.

The reasons why cytology of the vitreous aspirate does not always reveal malignant cells are numerous. The aspirate only contains a 
small number of cells. This seriously limits the possibilities for the cytologist. ${ }^{12}$ The specimen has to be examined immediately, otherwise a part of the already small number of cells will be lytic. ${ }^{12}$ The vitreotome may destroy some of the cells; therefore, a low cut rate is advisable. ${ }^{42}$ The cells are mixed with balanced salt solution in the vitrectomy tubes during aspiration, another possible reason for the rapid lysis of some cells. The aspirate passes through tubing, sterilised with ethylene oxide which also has a cytolytic effect. Finally, it is assumed that steroids are lympholytic and may affect the viability of the tumour cells. ${ }^{4}$

Vitrectomy not only has a diagnostic value but also plays a therapeutic role since vitreal cloudiness may be so dense that it causes severe visual loss.

OCULAR LOCALISATION OF NON-HODGKIN'S

LYMPHOMA AND DIFFERENTIAL DIAGNOSIS

Most cases of ocular lymphoma present as intermediate uveitis ( $88 \%$ in this series) with 'vitritis'. ${ }^{2-4}$ This is often associated with multiple small chorioretinal lesions (five of nine cases). Chorioretinal lesions are frequently mentioned in literature ${ }^{2461415}$ and sometimes these cases are initially diagnosed as birdshot retinopathy or multifocal pigment epitheliopathy. $^{2-4111316}$

In some cases the intraocular involvement is limited to the chorioretina without vitreous invasion. One of our patients (case 9), with already previously diagnosed small cell lymphoma, presented with a pure choroidal localisation without involvement of the vitreous. In such a case the ocular localisation can be confirmed with a chorioretinal biopsy. ${ }^{7417}$

\section{TREATMENT}

Eighty per cent of the patients with malignant non-Hodgkin's lymphoma will eventually die from complications of their CNS lesions. ${ }^{35}$ More exceptionally, patients will die from visceral lesions or from infection.

According to a previous study only demonstrable and proved localisations should be treated. ${ }^{3}$ In cases where there is only ocular involvement, vitrectomy without radiotherapy can restore vision. If the vitreous aspirate does not provide clear histological evidence of the disease steroid treatment is usually installed. If the aspirate is frankly positive and certainly in cases where there are signs of rapid growth, orbital radiotherapy is given. The advised dose ranges between 40 and $50 \mathrm{~Gy}{ }^{3}$ Side effects of this treatment include corneal ulcers (two of our cases), retinal vasculopathy, optic neuropathy, and cataract. Out of six patients receiving radiotherapy focused on the eyes, three developed cataract. Regarding the side effects of radiation the question has been raised whether these could not be reduced by combining a lower dose of radiotherapy with chemotherapy. ${ }^{3}$

Total brain irradiation of 45-50 Gy is most often performed in case the CNS is involved. ${ }^{3}$ Most lesions in the CNS form are found in the cerebral hemispheres, the white matter, the cerebellum, and the midbrain. Spinal lesions are rare.

As a general rule recurrences after radiotherapy are not treated by irradiation but by chemotherapy. ${ }^{3}$ Intrathecal methotrexate is often added, as was the case in two of our patients (cases 5 and 9).

\section{PROGNOSIS}

Contrary to other localisations of nonHodgkin's lymphoma that actually can be treated by chemotherapy and/or radiation with good results, ${ }^{18}$ patients with an ocular nonHodgkin's lymphoma have a limited life expectancy. ${ }^{2-4}$ The average survival after diagnosis in this group of patients was 31 months. Only a few patients survive for more than 3 years. $^{2-4}$ Typically, patients initially react favourably and sometimes in a spectacular way to the treatment-radiotherapy, steroids, and chemotherapy, alone or in combination. ${ }^{2}$ However, most of them will have recurrences at the same site or elsewhere, and these eventually will be fatal.

Our youngest patient (case 5) had five recurrences during the 5 years that she survived after the diagnosis. In between the recurrences she was able to lead a more or less normal life.

\section{Conclusion}

Primary ocular non-Hodgkin's lymphoma is a difficult diagnosis. The diagnosis is often only considered after a variable period of uveitis unresponsive to treatment. A high index of suspicion is mandatory. Vitrectomy allows a cytological diagnosis in most but not in all cases.

Primary ocular or oculo-CNS large cell nonHodgkin's lymphoma has a dramatic course. Once CNS involvement is present, survival is only a matter of weeks without treatment. Treatment with radiotherapy, steroids, and chemotherapy, separate or in combination, can often induce remission. Recurrences, however, are the rule and the patients eventually die after a few years. Treatment allows some of these patients to lead a relatively normal and active life in between the recurrences.

As far as ocular involvement is concerned, steroid treatment with vitrectomy, combined or not with orbital radiotherapy, can save some vision in these patients. Corneal ulcers and cataract are frequent complications of the ocular treatment. Cataract surgery, sometimes associated with vitrectomy, usually gives a favourable result.

1 Barr CC, Joondeph HC. Retinal periphlebitis as the initial clinical finding in a patient with Hodgkin's disease. Retina 1984;3:253-7.

2 Peterson K, Gordon K, Heinemann M, Deangelis L. The clinical spectrum of ocular lymphoma. Cancer 1993;72: 843-9.

3 Rankin GA, Jakobiec FA, Hidayat AA. Intraocular lymphoproliferations simulating uveitis. In: Albert DM, Jakobiec FA, eds. Principles and practice of ophthalmology. Philadelphia: WB Saunders, 1994:524-48.

4 Whitcup SM, Desmet MD, Rubin BI, Palestine AG, Martin $\mathrm{BF}$, Burnier M, et al. Intraocular lymphoma. Clinical and
histopathologic diagnosis. Ophthalmology 1993;100:1399406 .

506.

Freeman LM, Schachat AP, Knox DL, Michels RG, Green WR. Clinical features, laboratory investigations and survival in ocular reticulum cell sarcoma. Ophthalmology 1987;94:1631-9. 
6 Gass JDM, Sever RJ, Grizzard WS, Clarkson JG, Blumenkranz $\mathrm{M}$, Wind CA, et al. Multifocal pigment epithelial detachments by reticulum cell sarcoma. A characteristic funduscopic picture. Retina 1984;4:135-43.

7 Lafaut BA, Hanssens M, Verbraeken H, De Laey JJ. Chorioretinal biopsy in the diagnosis of intraocular lymphoma: a case report. Bull Soc Belge Ophtalmol 1994;252:67-73.

8 Fredrick DR, Char DH, Ljung BM, Brinton DA. Solitary intraocular lymphoma as an initial presentation of widespread disease. Arch Ophthalmol 1989;107:395-7.

9 Guyer DR, Green WR, Schachat AP, Bastacky S, Miller NR. Bilateral ischemic optic neuropathy and retinal vascular occlusions associated with lymphoma and sepsis. Clinicopathologic correlation. Ophthalmology 1990;97:882-8.

10 Strominger MB, Schatz NJ, Glaser JS. Lymphomatous optic neuropathy. Am f Ophthalmol 1993;119:774-6.

11 Buettner H, Bollins J. Intravitreal large-cell lymphoma. Mayo Clin Proc 1993;68:1011-5.

12 Davis J, Chan CC, Nussenblatt R. Diagnostic vitrectomyin intermediate uveitis. In: Boke WRF, Manthey KF, Nussenblatt R, eds. Intermediate uveitis. Dev Ophthalmol. Basel: Karger, 1992;23:120-32.
13 Foulds W. The uses and limitations of intraocular biopsy. Eye 1992;6:11-27.

14 Kirman M, Thomas E, Rao N, Laborde R. Intraocular reticulum cell sarcoma: diagnosis by choroidal biopsy. $B r F$ Ophthalmol 1987;71:748-52.

15 Lang SK, Surer JL, Green WR, Finkelstein D, Michels RG, Maumenee AF. Ocular reticulum cell sarcoma. Retina 1985;5:79-86.

16 Priem H, Verbraeken H, De Laey JJ. Diagnostic problems in chronic vitreous inflammation. Graefes Arch Clin Exp Ophthalmol 1993;231:453-6.

17 Martin DF, Chan CC, Desmet MD, Palestine AG, Davis JL, Whitcup SM, et al. The role of chorioretinal biopsy in the management of posterior uveitis. Ophthalmology 1993;100: 705-14.

18 Lambertenghi-Deliliers G, Butti C, Baldini L, Ceriani A, Lombardi F, Luoni M, et al. A cooperative study of epirubicin with cyclophosphamide, micristine and prednisone (CEOP) in non-Hodgkin's lymphoma. Haematologica 1995;80:318-24. 